\title{
BMJ
}

\section{Effect of oxandrolone and timing of pubertal induction on final height in Turner's syndrome: randomised, double blind, placebo controlled trial}

\author{
Emma Jane Gault, research associate, ${ }^{1}$ Rebecca J Perry, locum consultant paediatrician, ${ }^{1}$ Tim J Cole, professor \\ of medical statistics, ${ }^{2}$ Sarah Casey, pharmacy clinical trials technician, ${ }^{3}$ Wendy F Paterson, auxologist, ${ }^{1}$ Peter C \\ Hindmarsh, professor of paediatric endocrinology, ${ }^{4}$ Peter Betts, consultant paediatrician (retired), ${ }^{5}$ David B \\ Dunger, professor of paediatrics, ${ }^{6}$ Malcolm D C Donaldson, senior lecturer in child health ${ }^{1}$ on behalf of the \\ British Society for Paediatric Endocrinology and Diabetes
}

University of Glasgow Department of Child Health, Royal Hospital for Sick Children, Glasgow G3 8SJ, UK

${ }^{2}$ MRC Centre of Epidemiology for Child Health, UCL Institute of Child Health, London, UK

${ }^{3}$ Clinical Trials Department, Pharmacy Department, Royal Hospital for Sick Children,

Glasgow

${ }^{4}$ Clinical and Molecular Genetics Unit, UCL Institute of Child Health, London

${ }^{5}$ Department of Paediatrics, Southampton University Hospitals NHS Trust, Southampton, UK

${ }^{6}$ University of Cambridge Department of Paediatrics, Addenbrooke's Hospital,

Cambridge, UK

Correspondence to: $\mathrm{M}$ Donaldson malcolm.donaldson@glasgow.ac. uk

Cite this as: BMJ 2011;342:d1980 doi:10.1136/bmj.d1980 ovarian failure at 12 years were further randomised to oral cell line in a phenotypic female. The phenotype is

\section{ABSTRACT}

Objective To examine the effect of oxandrolone and the timing of pubertal induction on final height in girls with Turner's syndrome receiving a standard dose of growth hormone.

Design Randomised, double blind, placebo controlled trial.

Setting 36 paediatric endocrinology departments in UK hospitals.

Participants Girls with Turner's syndrome aged $7-13$ years at recruitment, receiving recombinant growth hormone therapy $\left(10 \mathrm{mg} / \mathrm{m}^{2} /\right.$ week).

Interventions Participants were randomised to oxandrolone $(0.05 \mathrm{mg} / \mathrm{kg} /$ day, maximum $2.5 \mathrm{mg} /$ day $)$ or placebo from 9 years of age. Those with evidence of ethinylestradiol (year 1, $2 \mu \mathrm{g}$ daily; year 2, $4 \mu \mathrm{g}$ daily; year 3, 4 months each of 6,8 , and $10 \mu \mathrm{g}$ daily) or placebo; participants who received placebo and those recruited after the age of 12.25 years started ethinylestradiol at age 14

Main outcome measure Final height.

Results 106 participants were recruited, of whom 14 withdrew and 82/92 reached final height. Both oxandrolone and late pubertal induction increased final height: by 4.6 ( $95 \%$ confidence interval 1.9 to 7.2$) \mathrm{cm}$ $(P=0.001, n=82)$ for oxandrolone and $3.8(0.0$ to 7.5$) \mathrm{cm}$ $(P=0.05, n=48)$ for late pubertal induction with ethinylestradiol. In the 48 children who were randomised twice, the effects on final height (compared with placebo and early induction of puberty) of oxandrolone alone, late induction alone, and oxandrolone plus late induction were similar, averaging 7.1 (3.4 to 10.8) cm (P<0.001). No cases of virilisation were reported.

Conclusion Oxandrolone had a positive effect on final height in girls with Turner's syndrome treated with growth hormone, as did late pubertal induction with ethinylestradiol at age 14 years. However, these effects were not additive, so using both had no advantage. Oxandrolone could, therefore, be offered as an alternative to late pubertal induction for increasing final height in Turner's syndrome.

Trial registration Current Controlled Trials ISRCTN50343149.

\section{INTRODUCTION}

Turner's syndrome can be defined as absence or abnormality of the second $\mathrm{X}$ chromosome in a major highly variable, but short stature and gonadal dysgenesis are usually present. Short stature in Turner's syndrome relates to impairment of each phase of the infancy-childhood-puberty model of growth, ${ }^{1}$ and it results in a mean untreated final height approximately $21 \mathrm{~cm}$ below that of the unaffected female population. ${ }^{2}$ The mainstay of treatment for short stature is recombinant growth hormone, available since 1985 and licensed for use in Turner's syndrome. Studies have shown its efficacy in improving height velocity and final height, although individual outcomes vary markedly. ${ }^{3-10}$

The adjunctive use in Turner's syndrome of the anabolic steroid oxandrolone remains controversial. When given in combination with growth hormone treatment, some studies have reported improved final height, ${ }^{611} 12$ whereas others have reported little or no effect. ${ }^{13-15}$ The high doses used in early studies were associated with virilisation, ${ }^{61214}$ and even low doses, as reported in a recent Dutch publication, may be problematic. ${ }^{15}$ These potential adverse effects must be balanced against potential improvement in growth.

Most girls with Turner's syndrome need oestrogen therapy during adolescence to induce pubertal development. ${ }^{16}$ However, the optimal age at which to begin remains controversial; some people advocate a delay to extend the growth period and increase final height, ${ }^{561718}$ whereas others have highlighted psychological problems of delaying pubertal development, suggesting that the benefits are marginal. ${ }^{19}$ The British Society for Paediatric Endocrinology and Diabetes 
recognised the uncertainties relating to the use of oxandrolone and timing of pubertal induction and set up the UK Turner Study in 1999 to investigate them.

\section{METHODS}

Participants

Members of the British Society for Paediatric Endocrinology and Diabetes recruited patients from participating paediatric endocrinology departments in UK hospitals. Inclusion criteria for participation of patients were karyotype confirmed Turner's syndrome (all karyotypes were eligible, including mosaic), age 7-13 years, no previous growth hormone treatment or previous treatment in the range $8.3-11.7 \mathrm{mg} / \mathrm{m}^{2} /$ week in five to seven injections a week, no previous oxandrolone and oestrogen therapy, and open epiphyses. Exclusion criteria were major systemic illness that might affect growth and social or psychological difficulties likely to seriously impair concordance.

\section{Study design}

We devised a double blind, placebo controlled, randomised controlled trial, including two randomisations in a two by two factorial design. Figure 1 shows the flow chart of the design and participants. A steering committee (British Society for Paediatric Endocrinology and Diabetes Clinical Trials/Audit Group) supervised the study, and an independent data and safety monitoring group was established. All participants' parents gave written informed consent.

\section{Randomisation and masking}

The British Society for Paediatric Endocrinology and Diabetes Clinical Trials Unit (Cambridge, UK) used minimisation by weighted randomisation for the study's two randomisations. ${ }^{20}$ Randomisation 1 , to oxandrolone or placebo, took place at age 9 years (or at enrolment, if older) and was balanced for enrolling centre, quarter of mid-parental height, and previous exposure to growth hormone treatment. Randomisation 2 took place at age 12 years in girls with ovarian failure (basal serum follicle stimulating hormone concentration $>10 \mathrm{U} / \mathrm{L}$ ), with additional minimisation for randomisation 1, to begin oral ethinylestradiol or placebo at 12 years; the placebo group subsequently started ethinylestradiol at 14 years. Girls with a follicle stimulating hormone concentration below 10U/L and a karyotype associated with preservation of ovarian function $\left(45, \mathrm{X} / 46, \mathrm{XX}\right.$ and $\left.45, \mathrm{X} / 47, \mathrm{XXX}^{21}\right)$ (the spontaneous puberty group) were not randomised at randomisation 2. Girls with other karyotypes were tested for concentrations of gonadotrophin releasing hormone and were randomised at randomisation 2 if the peak follicle stimulating hormone concentration was above $30 \mathrm{U} / \mathrm{L}$. Participants enrolled after the age of 12 . 25 years and without spontaneous puberty (the late group) started ethinylestradiol at 14 years.

\section{Treatment}

All participants received the growth hormone preparation of their choice at $10 \mathrm{mg} / \mathrm{m}^{2} /$ week in daily subcutaneous injections. Oral oxandrolone (SPA, Milan, Italy) was given at $0.05 \mathrm{mg} / \mathrm{kg} /$ day, with a maximum daily dose of $2.5 \mathrm{mg}$. Oral ethinylestradiol (UCB Pharma, Slough, UK) was given daily as follows, regardless of the age at starting: year 1, $2 \mu \mathrm{g}$; year 2, $4 \mu \mathrm{g}$; year 3, four months each of 6,8 , and $10 \mu \mathrm{g}$. The code for randomisation 2 was broken at 15 years to allow introduction of progesterone therapy: oral norethisterone (CP Pharmaceuticals, Wrexham, UK) $5 \mathrm{mg}$ daily for five days each month.

Treatment with growth hormone and oxandrolone continued until final height was reached. Oestrogen/

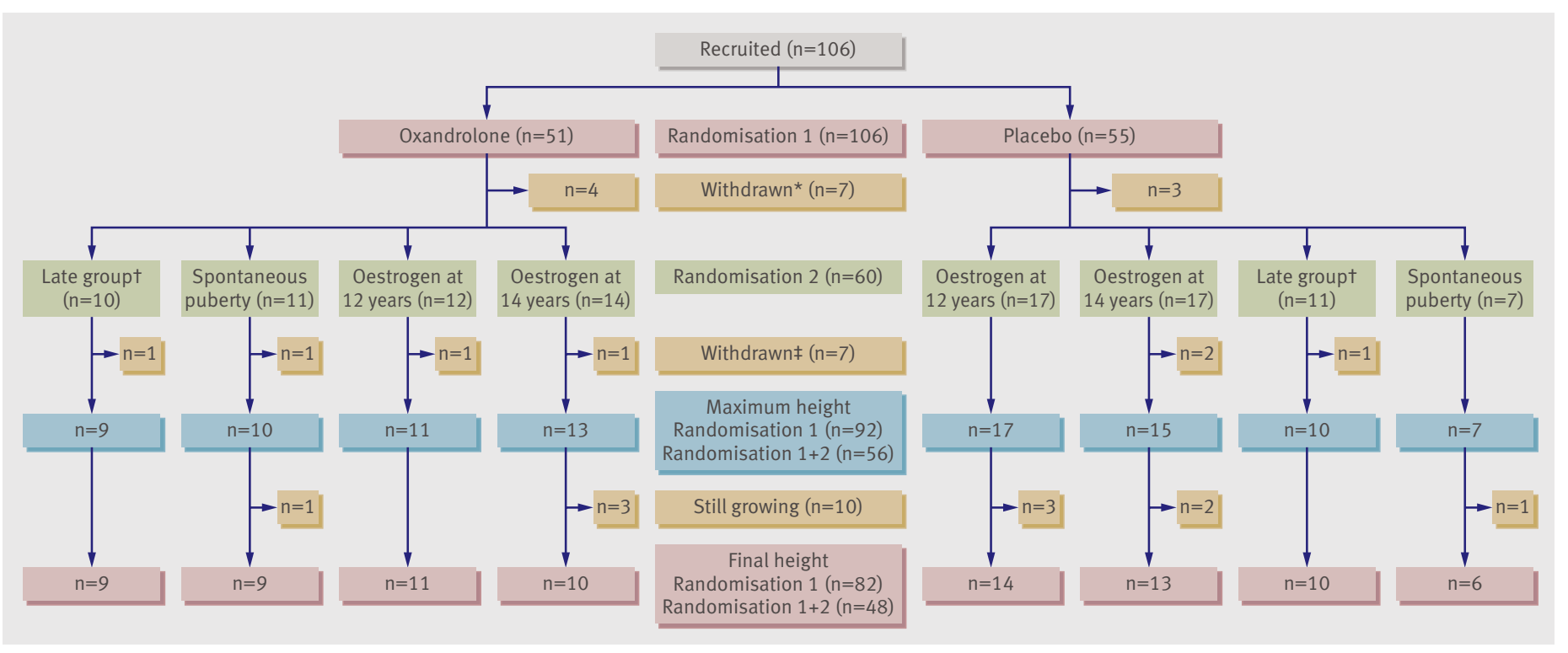

Fig 1 Flow chart of participation in UK Turner Study according to treatment groups, completions, and withdrawals. *Withdrawn before 12 years of age (that is, randomised only at randomisation 1 to oxandrolone or placebo). $\dagger$ Aged $\geq 12.25$ years at recruitment; oestrogen treatment started at 14 years with no randomisation. $\ddagger$ Withdrawn after 12 years of age (that is, randomised at randomisation 1 to oxandrolone or placebo and at randomisation 2 if oestrogen treatment needed) 
Table 1|Characteristics of participants at enrolment, maximum height, and final height, according to treatment group. Values are mean (SD) unless stated otherwise

\begin{tabular}{|c|c|c|c|c|c|c|c|c|c|}
\hline \multirow[b]{2}{*}{ Characteristics } & \multicolumn{2}{|c|}{$\begin{array}{c}\text { Randomised to } \\
\text { oestrogen at } 12 \text { years }\end{array}$} & \multicolumn{2}{|c|}{$\begin{array}{c}\text { Randomised to } \\
\text { oestrogen at } 14 \text { years }\end{array}$} & \multicolumn{2}{|c|}{$\begin{array}{c}\text { Late group (oestrogen at } \\
14 \text { years) }\end{array}$} & \multicolumn{2}{|c|}{ No oestrogen needed } & \multirow[b]{2}{*}{ Total } \\
\hline & Oxandrolone & Placebo & Oxandrolone & Placebo & Oxandrolone & Placebo & Oxandrolone & Placebo & \\
\hline At enrolment* & $(n=12)$ & $(n=17)$ & $(n=14)$ & $(n=17)$ & $(n=10)$ & $(n=11)$ & $(n=11)$ & $(n=7)$ & $(n=99)$ \\
\hline $\begin{array}{l}\text { Median (range) age } \\
\text { at diagnosis (years) }\end{array}$ & $0.1(0-9.8)$ & $4.6(0-9.2) \dagger$ & $4.5(0-9.8)$ & $1.5(0-9.8)$ & $2.8(0-12.7)$ & $3.1(0-13.4)$ & $6.6(0.7-10.4)$ & $8.3(0.5-10.1)$ & $3.8(0-13.4)$ \\
\hline Age (years) & $10.1(1.3)$ & $9.4(0.7)$ & $9.5(1.4)$ & $9.7(1.2)$ & $12.5(0.4)$ & $12.8(0.4)$ & $9.8(1.1)$ & $9.8(1.4)$ & $10.3(1.6)$ \\
\hline Height (cm) & $126.4(6.9)$ & $120.5(5.9)$ & $121.6(6.7)$ & $125.7(6.7)$ & $137.2(6.8)$ & $133.9(4.2)$ & $124.4(7.4)$ & $125(9.2)$ & $126.2(8.3)$ \\
\hline Height SD score & $-1.9(0.7)$ & $-2.4(0.8)$ & $-2.2(0.8)$ & $-1.8(0.8)$ & $-2.1(0.9)$ & $-2.9(0.6)$ & $-2.1(0.9)$ & $-2.0(0.8)$ & $-2.1(0.8)$ \\
\hline Target height $(\mathrm{cm})$ & $163.8(3.4)$ & $162.0(4.0)$ & $161.5(4.1)$ & $163.1(5.5)$ & $165.1(2.6)$ & $161.6(2.9)$ & $163.0(4.7)$ & $162.6(4.5)$ & $162.7(4.1)$ \\
\hline $\begin{array}{l}\text { Median (range) age } \\
\text { at growth hormone start } \\
\text { (years) }\end{array}$ & $5.4(4.0-10.2)$ & $7.3(2.4-10.1)$ & $6.1(2.2-10.5)$ & $4.2(2.4-9.6)$ & $8.3(4.5-12.8)$ & $9.5(4.0-13.8)$ & $6.0(3.2-10.9)$ & $8.7(1.7-10.3)$ & $6.4(1.7-13.8)$ \\
\hline $\begin{array}{l}\text { Median (range) duration of } \\
\text { growth hormone before } \\
\text { oestrogen induction (years) }\end{array}$ & $6.6(1.8-8.0)$ & $4.7(1.9-9.6)$ & $7.9(3.5-11.9)$ & $9.8(4.4-11.6)$ & $5.7(1.2-9.5)$ & $4.5(0.2-10.0)$ & - & - & $6.6(0.2-11.9)$ \\
\hline At maximum height $\ddagger$ & $(n=11)$ & $(n=17)$ & $(n=13)$ & $(n=15)$ & $(n=9)$ & $(n=10)$ & $(n=10)$ & $(n=7)$ & $(n=92)$ \\
\hline Age (years) & $16.2(1.4)$ & $15.9(1.2)$ & $16.2(1.5)$ & $16.8(1.0)$ & $17.0(1.0)$ & $17.9(1.0)$ & $14.9(0.8)$ & $15.0(0.9)$ & $16.3(1.4)$ \\
\hline Height (cm) & $154.4(3.9)$ & $147.2(7.0)$ & $153.0(8.1)$ & $152.0(6.8)$ & $155.3(4.3)$ & $148.9(6.0)$ & $151.9(6.0)$ & $150.2(6.2)$ & $151.4(6.7)$ \\
\hline Height SD score & $-1.4(0.7)$ & $-2.5(1.2)$ & $-1.5(1.1)$ & $-1.9(1.1)$ & $-1.3(0.7)$ & $-2.4(1.0)$ & $-1.5(1.0)$ & $-1.8(0.9)$ & $-1.8(1.1)$ \\
\hline Change in height SD score & $0.6(0.5)$ & $-0.1(0.6)$ & $0.7(1.0)$ & $-0.1(0.7)$ & $0.7(0.8)$ & $0.5(0.8)$ & $0.5(1.0)$ & $0.2(0.7)$ & $0.3(0.8)$ \\
\hline At final height§ & $(n=11)$ & $(n=14)$ & $(n=10)$ & $(n=13)$ & $(n=9)$ & $(n=10)$ & $(n=9)$ & $(n=6)$ & $(n=82)$ \\
\hline Age (years) & $16.2(1.4)$ & $16.2(0.8)$ & $16.8(0.8)$ & $17.2(0.9)$ & $17.0(1.0)$ & $17.9(1.0)$ & $15.0(0.9)$ & $15.2(1.0)$ & $16.5(1.3)$ \\
\hline Height $(\mathrm{cm})$ & $154.4(3.9)$ & $147.0(7.4)$ & $155.1(4.1)$ & $153.1(6.7)$ & $155.3(4.3)$ & $148.9(6.0)$ & $151.8(6.4)$ & $149.4(6.4)$ & $151.8(6.4)$ \\
\hline Height SD score & $-1.4(0.7)$ & $-2.6(1.2)$ & $-1.4(0.7)$ & $-1.7(1.1)$ & $-1.3(0.7)$ & $-2.4(1.0)$ & $-1.5(1.1)$ & $-2.0(0.9)$ & $-1.8(1.0)$ \\
\hline Change in height SD score & $0.6(0.5)$ & $-0.3(0.5)$ & $0.9(0.9)$ & $-0.1(0.8)$ & $0.7(0.8)$ & $0.5(0.8)$ & $0.3(1.0)$ & $0.1(0.9)$ & $0.3(0.8)$ \\
\hline \multicolumn{10}{|c|}{$\begin{array}{l}\text { *Excluding } 7 \text { withdrawn participants: } 1 \text { immediately after enrolment, so no baseline data available; } 6 \text { before age } 12 \text {, who were randomised only at randomisation } 1 \text { ( } 4 \text { oxandrolone, } 2 \\
\text { placebo). } \\
\text { †Excluding } 2 \text { antenatal diagnoses. } \\
\text { †Excluding } 14 \text { withdrawn participants (that is, including } 82 \text { at final height and } 10 \text { yet to reach final height). } \\
\text { §Excluding } 14 \text { withdrawn participants and } 10 \text { yet to reach final height. }\end{array}$} \\
\hline
\end{tabular}

progesterone therapy continued at an adult replacement dose once pubertal induction was completed.

White, uncoated, flat bevelled edge placebo tablets ( 7 and $5 \mathrm{~mm}$ in diameter) (Essential Nutrition, Brough, UK) were specially manufactured to match the size, weight, and appearance of oxandrolone $2.5 \mathrm{mg}$ and ethinylestradiol $2 \mu \mathrm{g}$ tablets respectively. The study's central pharmacy (Royal Hospital for Sick Children, Glasgow, UK) supplied all tablets in a double blind, placebo controlled fashion; only staff at the British Society for Paediatric Endocrinology and Diabetes Clinical Trials Unit and the central distributing pharmacy were not blinded to treatment allocations.

\section{Oxandrolone supplies}

In 2004 and 2008, the sole European manufacturer of oxandrolone $2.5 \mathrm{mg}$ ceased production, resulting in 34 participants in 2004 and 11 in 2008 temporarily suspending active oxandrolone treatment (mean duration: 2004, 52 days; 2008, 163 days). In 2008, the decision was taken to terminate the treatment arm forthwith, resulting in eight participants stopping oxandrolone treatment prematurely.

\section{Study procedures}

At clinic visits every four to six months, height was measured with a Harpenden stadiometer to the last completed $1 \mathrm{~mm}$ and converted to an SD score by using the British 1990 reference. ${ }^{22}$ Radiographs of the left wrist were obtained annually, and a single observer (WFP) analysed them for bone age estimation according to the Tanner Whitehouse II method. ${ }^{23}$ Biochemical analyses followed local protocols, and the results were reported centrally.

Standardised pharmacovigilance procedures were followed, with recording of adverse events or reactions at each visit and subsequent review by the Data and Safety Monitoring Group. Data collection ceased if participants withdrew consent, although we included previously collected data in the analysis.

\section{Statistical methods}

The primary outcome was final height, defined as height velocity less than $1 \mathrm{~cm} /$ year and bone age at least 15.5 years. Secondary outcomes were maximum height (that is, the most recently available height), age of attaining final height, and the three summary growth parameters from the SITAR analysis described below.

Assuming a standard deviation of $5 \mathrm{~cm}$, we needed 50 girls in each group to detect a difference between groups in mean final height of $2.8 \mathrm{~cm}$ with $80 \%$ power at 5\% significance-a total of 100 patients. The study was not formally powered to detect a significant interaction between the two randomisations. In the event, more than 100 patients were recruited, but fewer than 100 were followed up to final height. 

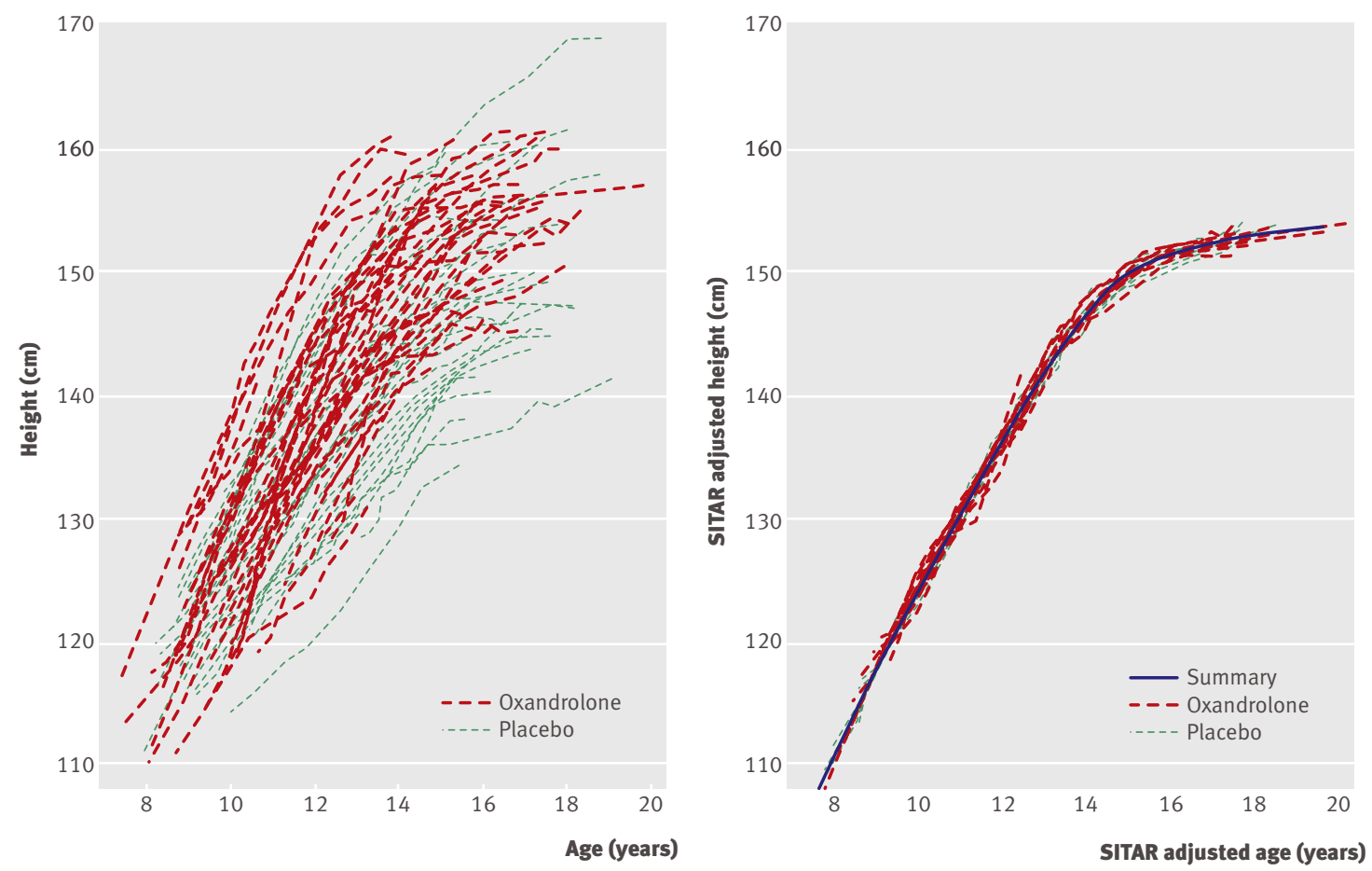

Fig 2 | Individual height growth curves according to randomisation 1: unadjusted (left) and SITAR adjusted (right)

We estimated the effects of the two randomisations separately by using multiple regression. We also adjusted randomisation 2 (timing of pubertal induction) for randomisation 1 (oxandrolone) and tested for an interaction.

In addition, we applied SITAR (superimposition by translation and rotation), a novel method of growth curve analysis, to the data. ${ }^{24}$ SITAR transforms individual growth curves so that they become essentially the same as each other and, when superimposed, define the average summary curve. To achieve this, each individual curve is suitably altered in three distinct ways: the curve is shifted up/down (a measure of the child's size in $\mathrm{cm}$ ) and left/right (a measure of growth tempo in years), and the age axis is stretched/squashed (a measure of percentage velocity). Size, tempo, and velocity are thus participant specific random effects summarising how each girl's curve differs from the average curve. The effects of the randomisations can be explored by comparing the values of the random effects by trial arm. Equally, separate summary curves can be constructed for each trial arm.

\section{RESULTS}

One hundred and six girls with Turner's syndrome were recruited from 36 UK hospitals between 1999 and 2003, of whom 14 withdrew (four of them because of early organisational errors), leaving 92 to complete the study (fig 1). The breakdown of karyotypes was 45 , X (39), 45,X/46,XX (18), 45,X/46,XrX (9), complex mosaics containing three or more cell lines (8), 45,X/46,XiX (7), 45,X/45,XY (7), 46,XX including a structural abnormality of second $\mathrm{X}(7), 45, \mathrm{X} / 46, \mathrm{XY}$ including a structural abnormality of $\mathrm{Y}(3), 45, \mathrm{X} / 46, \mathrm{XX}$ including a structural abnormality of second $\mathrm{X}(3)$, $45, \mathrm{X} / 47, \mathrm{XXX}(2)$, and other (3).

All 106 participants were randomised at or after 9 years of age to oxandrolone or placebo (randomisation 1), and 60 were also randomised at 12 years to early or late induction of puberty (randomisation 2). Of the 46 girls not randomised at 12 years, 21 enrolled after 12 years (the late group), 18 had spontaneous puberty, and seven had withdrawn before the age of 12 years.

Final and maximum height

Table 1 shows participants' characteristics at enrolment, at maximum height, and at final height by treatment group. At the time of writing, 82 participants had attained a mean final height of $151.8(\mathrm{SD} 6.4) \mathrm{cm}$, and 10 others continued growing. Table 2 shows details of final height and maximum height according to the study's two randomisations.

By twice randomised group, the mean final heights were placebo/early induction $147.0 \mathrm{~cm}$, placebo/late induction $153.1 \mathrm{~cm}$, oxandrolone/early induction $154.4 \mathrm{~cm}$, and oxandrolone/late induction $155.1 \mathrm{~cm}$ (table 1). Table 3 summarises the results of the randomised comparisons. For randomisation 1, final height was significantly greater with oxandrolone than placebo $(4.6 \mathrm{~cm}, 95 \%$ confidence interval 1.9 to 7.2 ; $\mathrm{P}=0.001)$. Similarly, for randomisation 2 , final height was significantly greater with pubertal induction at 14 years than at 12 years $(3.8 \mathrm{~cm}, 0.0$ to $7.5 ; \mathrm{P}=0.05)$.

However, the positive effects of oxandrolone and late induction were not additive. Among girls previously randomised to oxandrolone, the effect of late induction compared with early induction was clinically insignificant $(+0.7 \mathrm{~cm})$; in the placebo group, however, 
Table 2 | Final height and maximum height data for participants randomised twice, according to randomisation 1 (oxandrolone/placebo) and randomisation 2 (pubertal induction at 14/ 12 years). Values are mean (SD)

\begin{tabular}{|c|c|c|c|c|}
\hline \multirow[b]{2}{*}{ Measurement } & \multicolumn{2}{|c|}{ Randomisation 1} & \multicolumn{2}{|c|}{ Randomisation 2} \\
\hline & Oxandrolone & Placebo & $\begin{array}{l}\text { Induction at } \\
14 \text { years }\end{array}$ & $\begin{array}{l}\text { Induction } \\
\text { at } 12 \text { years }\end{array}$ \\
\hline Final height & $(n=39)$ & $(n=43)$ & $(n=23)$ & $(n=25)$ \\
\hline Age (years) & $16.2(1.4)$ & $16.7(1.3)$ & $16.9(0.8)$ & $16.1(1.2)$ \\
\hline Height (cm) & $154.2(4.7)$ & $149.6(7.0)$ & $154.0(5.7)$ & $150.2(7.1)$ \\
\hline Height SD score & $-1.4(0.7)$ & $-2.2(1.1)$ & $-1.6(0.9)$ & $-2.1(1.2)$ \\
\hline Change in height SD score & $0.7(0.8)$ & $0.0(0.8)$ & $0.3(1.0)$ & $0.1(0.7)$ \\
\hline Maximum height & $(n=43)$ & $(n=49)$ & $(n=28)$ & $(n=28)$ \\
\hline Age (years) & $16.0(1.4)$ & $16.5(1.3)$ & $16.6(1.2)$ & $16.0(1.3)$ \\
\hline Height $(\mathrm{cm})$ & $153.6(5.9)$ & $149.3(6.8)$ & $152.4(7.3)$ & $150.0(6.9)$ \\
\hline Height SD score & $-1.4(0.8)$ & $-2.2(1.1)$ & $-1.7(1.1)$ & $-2.0(1.1)$ \\
\hline Change in height SD score & $0.6(0.8)$ & $0.0(0.7)$ & $0.3(0.9)$ & $0.2(0.7)$ \\
\hline
\end{tabular}

late induction added $6.2 \mathrm{~cm}$ compared with early induction (table 3 , interaction). The two treatments together were thus no more effective than either one alone, as shown by the substantial and close to significant negative interaction. The mean effect on final height of oxandrolone, late induction of puberty, or both compared with placebo and early induction was $+7.1 \mathrm{~cm}$ (that is, the mean final height in the combined oxandrolone/early, oxandrolone/late, and placebo/ late groups compared with the placebo/early group), which is appreciably larger than the effects for either randomisation alone (table 3 , combination). This was because the randomisation analyses compared intervention and control groups in which half of each control group had received an effective intervention from the other randomisation, thus reducing the apparent

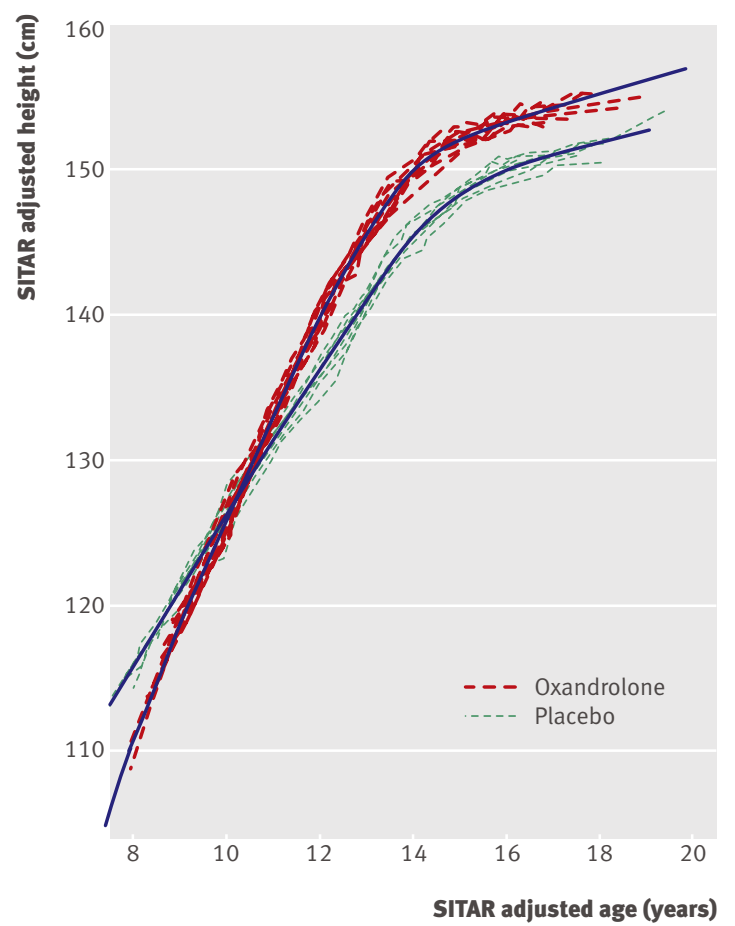

effect size. The standard deviation for the combined group was $5.1 \mathrm{~cm}$, rather less than the $7.4 \mathrm{~cm}$ for the placebo/early induction group $(\mathrm{P}=0.1)$, suggesting that treatment preferentially benefited the shortest girls.

Table 3 also includes the results for maximum height, based on the 92 girls still in the trial. The oxandrolone effect of $+4.3 \mathrm{~cm}(\mathrm{P}=0.002)$ was similar to that for final height $(+4.6 \mathrm{~cm})$, and the late induction effect of $+2.4 \mathrm{~cm}(\mathrm{P}=0.2)$ was appreciably smaller than the $+3.8 \mathrm{~cm}$ for final height. The age of attainment of final height was similar for oxandrolone and placebo (16.2 v 16.7 years; $\mathrm{P}=0.1$ ) and later, by design, for late versus early induction (16.9 v 16.1 years; $\mathrm{P}=0.009)$.

\section{SITAR analysis of height curves}

We applied the SITAR analysis to the 105 participants with at least one height measurement (one girl in the control group withdrew immediately after randomisation 1). Figure 2 shows individual height curves unadjusted (left panel) and SITAR adjusted with the summary curve (right panel). The curves are labelled according to randomisation 1 , and the oxandrolone curves tend to be above and to the left of the placebo curves.

The SITAR adjustment process estimated the size, tempo, and velocity parameters for each participant, which when applied to their curves made them all very similar, with a residual standard deviation of $0.6 \mathrm{~mm}$ around the summary curve (fig 2, right panel). Comparison of the mean values of the parameters by trial arm showed differences in size (oxandrolone $v$ placebo $+2.6 \mathrm{~cm} ; \mathrm{P}=0.02)$ but not tempo $(-0.3$ years; $\mathrm{P}=0.1)$, and the mean velocity was dramatically greater for oxandrolone (difference $+23 \%$, SE

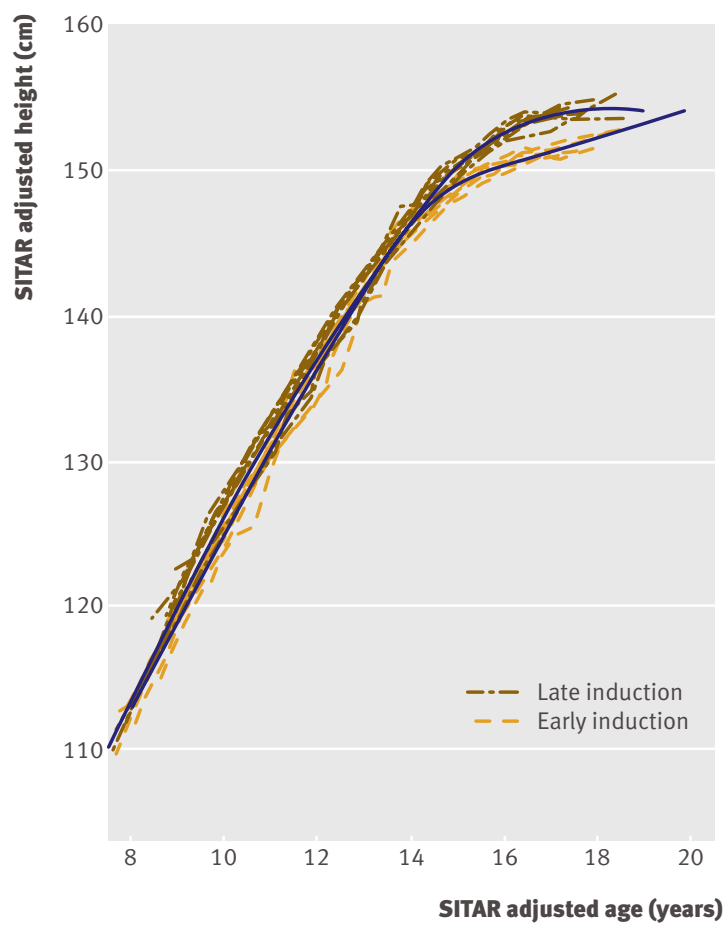


Table 3 |Effects of two randomisations, their interaction, and their combination, on mean final height and mean maximum height

\begin{tabular}{|c|c|c|c|c|}
\hline Randomisation & Mean/mean difference (SE) & Mean/mean difference (SE) & Difference $(95 \% \mathrm{Cl})$ & $P$ value \\
\hline Randomisation 1 & (Oxandrolone) & (Placebo) & & \\
\hline Final height $(\mathrm{cm})$ & $154.2(0.8)(n=39)$ & $149.6(1.1)(n=43)$ & 4.6 (1.9 to 7.2$)$ & 0.001 \\
\hline Maximum height (cm) & $153.6(0.9)(n=43)$ & $149.3(1.0)(n=49)$ & 4.3 (1.6 to 6.9) & 0.002 \\
\hline Randomisation 2 & (Induction at 14 years) & (Induction at 12 years) & & \\
\hline Final height $(\mathrm{cm})$ & $154.0(1.2)(n=23)$ & $150.2(1.4)(n=25)$ & $3.8(0.0$ to 7.5$)$ & 0.05 \\
\hline Maximum height (cm) & $152.4(1.4)(n=28)$ & $150.0(1.3)(n=28)$ & $2.4(-1.5$ to 6.2$)$ & 0.2 \\
\hline Interaction of R1 by R2* & $\begin{array}{c}\text { (Oxandrolone } \\
\text { (14 years-12 years)) }\end{array}$ & (Placebo (14 years -12 years)) & & \\
\hline Final height $(\mathrm{cm})$ & $0.7(1.7)(n=21)$ & $6.2(2.7)(n=27)$ & $-5.5(-12.4$ to 1.4$)$ & 0.1 \\
\hline Maximum height $(\mathrm{cm})$ & $-1.5(2.5)(n=24)$ & $4.7(2.5)(n=32)$ & $-6.2(-13.5$ to 1.2$)$ & 0.1 \\
\hline Combination of R1 and R2† & (Oxandrolone OR 14 years) & (Placebo AND 12 years) & & \\
\hline Final height $(\mathrm{cm})$ & $154.1(0.9)(n=34)$ & $147.0(2.0)(n=14)$ & 7.1 (3.4 to 10.8$)$ & $<0.001$ \\
\hline Maximum height $(\mathrm{cm})$ & $153.0(1.0)(n=39)$ & $147.2(1.7)(n=17)$ & 5.8 (1.9 to 9.7$)$ & 0.004 \\
\hline
\end{tabular}

$4 \% ; \mathrm{P}<0.001)$. This indicated that the developmental age scale in the oxandrolone arm was foreshortened by $23 \%$, increasing the velocity and making the oxandrolone curve correspondingly steeper than the placebo curve, although the age of final height was no earlier. This effect is seen in figure 3 (left panel), which shows SITAR summary curves calculated separately for oxandrolone and placebo. The two curves cross at 10 years, and height velocity is consistently greater in the oxandrolone arm.

Figure 3 (right panel) shows the corresponding comparison of summary height curves for randomisation 2 , late versus early induction. The differences here were smaller, the curves diverging only after 14 years; the late versus early comparisons for size $(+2.2 \mathrm{~cm})$ and velocity $(-9 \%)$ were statistically insignificant $(\mathrm{P}>0.1)$, whereas tempo was slightly delayed in the late induction arm $(+0.4$ years; $\mathrm{P}=0.06)$.

\section{Adverse events}

Between 1999 and 2009, 197 adverse events were reported; none of them were suspected to be unexpected serious adverse reactions. Ten were classified as serious adverse events, as they involved admission to hospital for procedures including appendicectomy and ear, nose, and throat surgery (for example, grommet (ventilation tube) insertion). Four adverse events could have been related to oxandrolone or ethinylestradiol: acne in a 15 year old (all study drugs were continued, and randomisation was later revealed as oxandrolone and pubertal induction at 14 years); persistent hypertension in a 13 year old (oxandrolone/ placebo was stopped and antihypertensive treatment started, blood pressure normalised, and oxandrolone/placebo treatment was restarted; the randomisation was later revealed as oxandrolone and pubertal induction at 12 years); abnormal liver function in a 16 year old (the participant was at near final height and elected to stop growth promoting treatment; randomisation was later revealed as oxandrolone and pubertal induction at 14 years); and episodic "hot flushes" in a 15 year old (all study drugs were continued; randomisation was later revealed as placebo and pubertal induction at 14 years). No virilisation was reported; in particular, no voice deepening or clitoromegaly was noted.

\section{DISCUSSION}

This randomised controlled trial of growth promoting treatment in Turner's syndrome showed a clear benefit to final height of oxandrolone treatment and of introducing ethinylestradiol for pubertal induction at age 14 rather than 12 years.

\section{Comparison with other studies}

This positive effect of oxandrolone on final height compares favourably with previous studies. ${ }^{561112}$ Early studies using high doses of oxandrolone had to reduce or stop treatment after reports of virilisation, ${ }^{6} 12$ and others showed little or no effect of oxandrolone. ${ }^{1314}$ However, they were retrospective in design and varied in treatment protocol. In contrast, the UK Turner Study used a prospective placebo controlled design, with consistent doses of oxandrolone throughout. A recent Dutch trial comparing growth hormone with two doses of oxandrolone $(0.03$ and $0.06 \mathrm{mg} / \mathrm{kg} /$ day) reported that the lower dose significantly increased adult "height gain" compared with placebo, whereas the higher dose did not. ${ }^{15}$ In contrast, the final height in both oxandrolone groups was only approximately $1 \mathrm{~cm}$ greater than placebo $(156.7 \mathrm{~cm}$ and $156.5 \mathrm{~cm}$ versus $155.6 \mathrm{~cm})$. The more favourable outcome in the UK study could be related to earlier age at starting growth hormone therapy (6.4 v 9 years) and also to the lower doses of oxandrolone given in the UK study $(0.05 \mathrm{mg} / \mathrm{kg} /$ day, maximum $2.5 \mathrm{mg}$ daily) compared with the $0.06 \mathrm{mg} / \mathrm{kg} /$ day arm of the Dutch study.

No adverse events directly attributable to oxandrolone were reported in the UK Turner Study; in particular, no virilisation was reported. Although 


\section{WHAT IS ALREADY KNOWN ON THIS TOPIC}

Growth hormone treatment improves growth and stature in girls with Turner's syndrome

However, the adjunctive use of the anabolic steroid oxandrolone remains controversial, with inconsistent reports of effect on growth and virilising side effects

Most girls with Turner's syndrome need oestrogen therapy for pubertal induction, but the optimal age at which to begin treatment and its subsequent effect on growth have yet to be established

\section{WHAT THIS STUDY ADDS}

A large cohort of girls with Turner's syndrome has been treated systematically over a 10 year period in this randomised, double blind, placebo controlled trial

Oxandrolone improved final height, as did delaying pubertal induction with ethinylestradiol from age 12 to 14 years, but doing both offered no added benefit

oxandrolone could have contributed to the cases of acne, hypertension, and abnormal liver function, causality cannot be assumed as these are commonly seen in Turner's syndrome. ${ }^{2526}$ By contrast, the Dutch study reported virilisation in 15/36 girls receiving $0.06 \mathrm{mg} /$ $\mathrm{kg} /$ day, which was severe enough for treatment to be discontinued in seven. However, patients receiving placebo also reported virilisation, and how these events were assessed is unclear. ${ }^{15}$ Furthermore, the maximum daily dose of $2.5 \mathrm{mg}$ used in the UK study irrespective of body weight could account for the absence of reported virilisation.

The UK Turner Study has also shown a positive effect on final height of introducing ethinylestradiol at age 14 rather than 12 years, consistent with the effect of oestrogen on epiphyseal fusion and supporting previous published associations between delayed pubertal induction and increased height. ${ }^{61318}$ Since 1999, however, concern has been expressed about the potential cardiovascular, skeletal, reproductive, and psychological consequences of prolonged oestrogen deficiency. ${ }^{1927-29}$ The finding that oxandrolone allows timely pubertal induction is thus attractive and in keeping with other work. ${ }^{30-34}$ This study shows that oxandrolone increases height velocity throughout the growing period yet does not materially advance the age of final height.

However, whereas both oxandrolone and late induction have been shown to increase final height, the two effects were not additive, so that giving either is beneficial but giving both is no better. One possible explanation for this is that there is a "ceiling" for the extra height available from growth promoting strategies in Turner's syndrome.

The subset of participants who were randomised twice and received oxandrolone had a larger "gain" in final height than did those who did not need any oestrogen treatment, whether they received oxandrolone or not. The numbers were too small to allow more detailed analysis, but we speculate that the girls who showed spontaneous puberty would have fused their epiphyses earlier than the other girls, which may have resulted in a less favourable final height.

\section{Strengths and limitations of study}

This randomised controlled trial has examined a large cohort of patients treated systematically over a 10 year period. Treatment has been well tolerated, such that dropout rates were low $(14 / 106)$ and the mean final height for the group to date $(151.8 \mathrm{~cm})$ is well above the target of $150 \mathrm{~cm}$ for girls with Turner's syndrome treated with growth hormone. ${ }^{63536}$

The number of girls who had completed the study and achieved final height at the time of analysis $(n=82)$ fell short of the target sample size of 100. Even when the remaining girls complete the study, the number evaluable at final height will still only be 92 . Despite this, however, the group of 82 girls has been sufficient to show positive effects of oxandrolone and delayed pubertal induction, and the addition of the 10 girls yet to complete is unlikely to materially alter the outcome. However, the failure to achieve the target sample size may have limited the ability to detect an interaction between the two randomisations.

Unfortunately, the break in production of oxandrolone $2.5 \mathrm{mg}$ tablets twice led to deviations from the protocol. Placebo tablets were unavailable for other oxandrolone preparations, and eventually the difficulties in supply led to the early termination of the treatment arm. Therefore, the results may underestimate the true effect of oxandrolone. Even so, they make a strong case for reintroduction of oxandrolone manufacture in Europe or, failing that, affordable importation, as costs of supplies from elsewhere are prohibitive.

Girls with mosaic Turner's karyotypes were included in the study. With a larger sample size, the effect of different karyotypes, with varying haploinsufficiency of the SHOX region, on height outcome could be examined. However, the group sizes of those who were randomised twice and attained final height were too small to allow further breakdown by karyotype.

A measure of bone mineral density was not included in the study protocol and would have provided valuable information. Although its value is now recognised in this patient group, the necessary scanning equipment was not routinely available at all participating centres when the study started.

\section{Conclusions and policy implications}

Oxandrolone has a positive effect on final height, as has inducing puberty at age 14 rather than 12 years. However, doing both offers no added benefit. We recommend, therefore, that when growth promotion is being considered in girls with Turner's syndrome, families are offered oxandrolone as an alternative to late pubertal induction.

We gratefully acknowledge the enduring support of the participants and their families over the past decade and their willingness to relinquish control over treatment decision making.

Contributors: $\mathrm{PB}, \mathrm{TJC}, \mathrm{MDCD}, \mathrm{DBD}$, and $\mathrm{PCH}$ were responsible for designing the study. PB, SC, MDCD, EJG, and WP carried out the study. TJC, MDCD, EJG, and RJP analysed the data. TJC, MDCD, DBD, EJG, PCH, and RJP prepared the manuscript. MDCD is the guarantor.

Funding: Funding was provided by the Scottish Executive Chief Scientist Office (1999-2004) (K/MRS/50/C2713) and thereafter by the British 
Society for Paediatric Endocrinology and Diabetes, with a contribution to funding of pharmacy staff from the Child Growth Foundation

Competing interests: All authors have completed the Unified Competing Interest form at www.icmje.org/coi_disclosure.pdf and declare: financial support from the Scottish Executive Chief Scientist Office (1999-2004), the British Society for Paediatric Endocrinology and Diabetes (20042011) and the Child Growth Foundation for the submitted work (MDCD, EJG, SC); travel expenses to attend an international meeting and a departmental honorarium for presenting preliminary results at a specialist nurse workshop (EJG); travel expenses from the British Society for Paediatric Endocrinology and Diabetes to attend study Steering Group meetings (MDCD, EJG); royalties from endocrine textbook, consultancy fees for medicolegal reports, and lecture fees from endocrine symposia (MDCD); board membership of Medtronic Diabetes and payment for expert testimony from the MHRA (PH); no other relationships or activities that could appear to have influenced the submitted work.

Ethical approval: The study was approved by the Scotland A Research Ethics Committee (formerly Multi-centre Research Ethics Committee for Scotland) (reference 98/0/92) and by local research ethics committees at participating centres, and written informed consent was obtained. A doctor/dentist exemption (DDX) certificate was obtained and later converted to a clinical trials authorisation (CTA reference 22931/0014/ 001) by the Medicines and Healthcare Products Regulatory Agency (MHRA).

Data sharing: No additional data available.

Steering group (British Society for Paediatric Endocrinology and Diabetes Clinical Trials/Audit Group): David Dunger (chair), Cambridge; Assunta Albanese (from March 2008), London; Tim Cole, London; John Gregory (from March 2008), Cardiff; Catherine Hall (May 2005 to February 2009), Manchester; Peter Hindmarsh, London; Chris Kelnar, Edinburgh; Jeremy Kirk (until October 2008), Birmingham; Justin Warner (from October 2008), Cardiff. Co-opted members: Malcolm Donaldson, Glasgow; Tim Cheetham, Newcastle. Data and Safety Monitoring Group: Forrester Cockburn, Glasgow; Michael Preece, London; Vincent Yeung, London (1999-2004). The study statistician, Tim Cole, London, also attended meetings.

Participating investigators and centres (including medical, nursing, research, secretarial, and pharmacy staff): Peter Smail and Amalia Mayo (Royal Aberdeen Children's Hospital); Dennis Carson (Royal Belfast Hospital for Sick Children); Jeremy Kirk (Birmingham Children's Hospital) Stephen Rose (Birmingham Heartlands Hospital); Elizabeth Crowne and Christine Burren (Bristol Royal Hospital for Sick Children); David Dunger, leuan Hughes, and Carlo Acerini (Addenbrooke's Hospital, Cambridge); John Gregory and Justin Warner (University Hospital of Wales, Cardiff); Christine Burren, Atanu Dutta, Assunta Albanese, and Aileen Alston (Queen Mary's Hospital for Children, Carshalton); Tracy Tinklin (Derbyshire Children's Hospital); Stephen Greene (Ninewells Hospital, Dundee); Chris Kelnar and Louise Bath (Royal Hospital for Sick Children, Edinburgh); Paul Williams and Tony Hulse (Medway Maritime Hospital, Gillingham); Malcolm Donaldson (Royal Hospital for Sick Children, Glasgow); Mehul Dattani and Caroline Brain (Great Ormond Street Children's Hospital, London); Martin Becker (Hinchingbrooke Hospital, Huntingdon); Gary Butler, Sabah Alvi, and Talat Mushtaq (Leeds Genera Infirmary); Peter Clayton and Catherine Hall (Manchester Children's Hospital); Mohammed Kibirige and Ginny Birrell (James Cook University Hospital, Middlesbrough); Philip Latham (Milton Keynes General Hospital); Tim Cheetham and Debbie Matthews (Royal Victoria Infirmary, Newcastle-upon-Tyne); Jeremy Allgrove (Newham General Infirmary); John Barton (Royal Gwent Hospital, Newport); Derek Johnston, Tabitha Randell, and Louise Denvir (Queen's Medical Centre, Nottingham); Vipan Datta and Melanie Kershaw (George Eliot Hospital, Nuneaton); Julie Edge, Fiona Ryan, and Justin Warner (John Radcliffe Hospital, Oxford); Joanna Walker (St Mary's Hospital, Portsmouth); Andrew Boon, Nicholas Mann, and Gary Butler (Royal Berkshire Hospital, Reading); Peter Stutchfield (Glan Clwyd Hospital, Rhyl); Martin Savage and Jeremy Allgrove (Royal London Hospital); Jerry Wales and Neil Wright (Sheffield Children's Hospital); Peter Betts and Justin Davies (Southampton General Hospital); John Schulga (Stirling Royal Infirmary); Janet King (Great Western Hospital, Swindon); Heather Stirling (Walsgrave Hospital); Kausik Banerjee, Paramita Cifelli, and Simon Whitmarsh (Whipps Cross Hospital); Janet Anderson (New Cross Hospital, Wolverhampton). Bone age interpretation: Wendy Paterson, Glasgow. Centralised pharmacy services: Sarah Casey and James Wallace, Glasgow.
1 Karlberg J. A biologically-oriented mathematical model (ICP) for human growth. Acta Paediatr 1989;78:70-94.

2 Rochiccioli P, David M, Malpuech G, Colle M, Limal JM, Battin J, et al. Study of final height in Turner's syndrome: ethnic and genetic influences. Acta Paediatr 1994;83:305-8.

3 Plotnick L, Attie KM, Blethen SL, Sy IP. Growth hormone treatment of girls with Turner syndrome: the National Cooperative Growth Study experience. Pediatrics 1998;102:479-81.

4 Takano K, Shizume K, Hibi I, Ogawa M, Okada Y, Suwa S, et al. Longterm effects of growth hormone treatment on height in Turne syndrome: results of a 6-year multicentre study in Japan. Horm Res 1995;43:141-3.

5 Nilsson KO, Albertsson-Wikland K, Alm J, Aronson S, Gustafsson J, Hagenäs L, et al. Improved final height in girls with Turner's syndrome treated with growth hormone and oxandrolone. J Clin Endocrinol Metab 1996;81:635-40.

6 Rosenfeld RG, Attie KM, Frane J, Brasel JA, Burstein S, Cara JF, et al. Growth hormone therapy of Turner's syndrome: beneficial effect on adult height. J Pediatr 1998;132:319-24.

7 Carel J-C, Mathivon L, Gendrel C, Ducret J-P, Chaussain J-L. Near normalization of final height with adapted doses of growth hormone in Turner's syndrome. J Clin Endocrinol Metab 1998;83:1462-6.

8 Sas T, de Muinck Keizer-Schrama S, Stijnen T, Jansen M, Otten BJ, Hoorweg-Nijman JJG, et al. Normalization of height in girls with Turner syndrome after long-term growth hormone treatment: results of a randomized dose-response trial. / Clin Endocrinol Metab 1999;84:4607-12.

9 Canadian Growth Hormone Advisory Committee. Impact of growth hormone supplementation on adult height in Turner syndrome: results of the Canadian randomized controlled trial. . Clin Endocrinol Metab 2005;90:3360-6.

10 Baxter L, Bryant J, Cave CB, Milne R. Recombinant growth hormone for children and adolescents with Turner syndrome (review). Cochrane Database Syst Rev 2007:1:CD003887.

11 Haeusler G, Schmitt K, Blümel P, Plöchl E, Waldhör T, Frisch H. Growth hormone in combination with anabolic steroids in patients with Turner syndrome: effect on bone maturation and final height. Acta Paediatr 1996;85:1408-14

12 Stahnke N, Keller E, Landy H, for the Serono Study Group. Favourable final height outcome in girls with Ullrich-Turner syndrome treated with low-dose growth hormone together with oxandrolone despite starting treatment after 10 years of age. J Pediatr Endocrinol Metab 2002;15:129-38.

13 Cacciari E, Mazzanti L, for the Italian Study Group for Turner Syndrome. Final height of patients with Turner's syndrome treated with growth hormone $(\mathrm{GH})$ : indications for $\mathrm{GH}$ therapy alone at high doses and late estrogen therapy. I Clin Endocrinol Metab 1999;84:4510-5.

14 Rochiccioli P, Battin J, Bertrand AM, Bost M, Cabrol S, le Bouc Y, et al. Final height in Turner syndrome patients treated with growth hormone. Horm Res 1995;44:172-6.

15 Menke LA, Sas TCJ, de Muinck Keizer-Schrama S, Zandwijken GRJ, de Ridder MAJ, Odink RJ, et al. Efficacy and safety of oxandrolone in growth hormone-treated girls with Turner syndrome. J Clin Endocrinol Metab 2010;95:1151-60.

16 Lippe B. Turner syndrome. Endocrinol Metab Clin North Am 1991;20:121-52.

17 Chernausek SD, Attie KM. Role of oestrogen therapy in the management of short stature in Turner syndrome. Acta Paediatr 1999;88:130-2.

18 Chernausek SD, Attie KM, Cara JF, Rosenfeld RG, Frane J, for the Genentech Inc Collaborative Study Group. Growth hormone therapy of Turner syndrome: the impact of age of estrogen replacement on final height. J Clin Endocrinol Metab 2000;85:2439-45.

19 Carel JC, Elie C, Ecosse E, Tauber M, Leger J, Cabrol S, et al. Selfesteem and social adjustment in young women with Turner syndrome-influence of pubertal management and sexuality: population-based cohort study. I Clin Endocrinol Metab 2006;91:2972-9.

20 Evans S, Royston P, Day S. Minim: allocation by minimisation in clinical trials. 2004. www-users.york.ac.uk/ mb55/guide/minim. htm.

21 Blair J, Tolmie J, Hollman A, Donaldson M. Phenotype, ovarian function, and growth in patients with 45,X/47,XXX Turner mosaicism: implications for prenatal counseling and estrogen therapy at puberty. / Pediatr 2001:139:724-8.

22 Freeman JV, Cole TJ, Chinn S, Jones PR, White EM, Preece MA. Cross sectional stature and weight reference curves for the UK, 1990. Arch Dis Child 1995; 73:17-24

23 Tanner JM, Whitehouse RH, Cameron N, Marshall WA, Healy MJR, Goldstein H. Assessment of skeletal maturity and prediction of adult height (TW2 method). Academic Press, 1983.

24 Cole TJ, Donaldson MDC, Ben-Shlomo Y. SITAR-a useful instrument for growth curve analysis. Int J Epidemiol 2010;39:1558-66. 
25 Nathwani NC, Unwin R, Brook CGD, Hindmarsh PC. Blood pressure and Turner syndrome. Clin Endocrinol 2000;52:363-70.

26 Salerno M, Di Maio S, Gasparini N, Rizzo M, Ferri P, Vajro P. Liver abnormalities in Turner syndrome. Eur J Pediatr 1999;158:618-23.

27 Davenport ML. Moving toward an understanding of hormone replacement therapy in adolescent girls: looking through the lens of Turner syndrome. Ann N Y Acad Sci 2008;1135:126-37.

28 Högler W, Briody J, Moore B, Garnett S, Lu PW, Cowell CT. Importance of estrogen on bone health in Turner syndrome: a cross-sectional and longitudinal study using dual-energy x-ray absorptiometry. J Clin Endocrinol Metab 2004;89:193-9.

29 Bannink EMN, van Sassen C, van Buuren S, de Jong FH, Lequin M, Mulder PGH, et al. Puberty induction in Turner syndrome: results of oestrogen treatment on development of secondary sexual

characteristics, uterine dimensions and serum hormone levels. Clin Endocrinol 2009;70:265-73.

30 Rosenfield RL, Perovic N, Devine N, Mauras N, Moshang T, Root AW, et al. Optimizing estrogen replacement treatment in Turner syndrome. Pediatrics 1998;102:486-8.

31 Sas TC, de Muinck Keizer-Schrama SMPF, Stijnen T, Asarfi A, van Leeuwen WJ, van Teunenbroek A, et al. A longitudinal study on bone mineral density until adulthood in girls with Turner's syndrome participating in a growth hormone injection frequency-response trial. Clin Endocrinol 2000;52:531-6.

32 Reiter EO, Blethen SL, Baptista J, Price L. Early initiation of growth hormone treatment allows age-appropriate estrogen use in Turner's syndrome. J Clin Endocrinol Metab 2001;86:1936-41.

33 Soriano-Guillen L, Coste J, Ecosse E, Leger J, Tauber M, Cabrol S, et al. Adult height and pubertal growth in Turner syndrome after treatment with recombinant growth hormone. J Clin Endocrinol Metab 2005;90:5197-204.

34 Davenport ML, Crowe BJ, Travers SH, Rubin K, Ross JL, Fechner PY, et al. Growth hormone treatment of early growth failure in toddlers with Turner syndrome: a randomized, controlled, multicenter trial. J Clin Endocrinol Metab 2007;92:3406-16.

35 Gault EJ, Paterson WF, Young D, Donaldson MDC. Improved final height in Turner's syndrome following growth-promoting treatment at a single centre. Acta Paediatr 2003;92:1033-8.

36 Johnston DI, Betts PR, Dunger DB, Barnes N, Swift PGF, Buckler JMH, et al. A multicentre trial of recombinant growth hormone and low dose oestrogen in Turner syndrome: near final height analysis. Arch Dis Child 2001;84:76-81.

Accepted: 14 February 2011 